\title{
Normal Pressure Hydrocephalus versus Atrophic Dilatation to Distinguish and Predict the Benefits of Surgical Intervention with a Phase-Contrast MRI Technique
}

\section{Atrofik Dilatasyonu Normal Basinçlı Hidrosefaliden Ayurt Etmek ve Faz Kontrast MRG ile Cerrahi Faydayı Öngörme}

Kerim ASLAN ${ }^{1}$, Onur TOKATLIOGLU ${ }^{2}$, Ramazan AYDIN ${ }^{3}$, Ahmet Veysel POLAT ${ }^{1}$, Lutfi INCESU

${ }^{1}$ Ondokuz Mayis University, School of Medicine, Department of Radiology, Samsun, Turkey

${ }_{2}^{2}$ Private Samsun Büyük Anadolu Hospital, Department of Radiology, Samsun, Turkey

${ }^{3}$ Physical Medicine and Rehabilitation Hospital, Department of Radiology, Samsun, Turkey

Corresponding Author: Kerim ASLAN / E-mail: mdkerim@hotmail.com

\begin{abstract}
AIM:To compare mean cerebrospinal fluid (CSF) volume in the aqueduct by using phase-contrast magnetic resonance imaging for the patients with idiopathic normal pressure hydrocephalus (INPH) and atrophic dilation (AD) to investigate the efficacy of this technique in predicting surgery.

MATERIAL and METHODS: The MR images of a total of 80 individuals, consisting of 30 patients considered to have INPH, 20 patients with $A D$ not proportional with cerebral sulci, and 30 control cases without a hydrocephalus clinical picture, were evaluated retrospectively. The minute mean aqueductal CSF flow rates of the three groups were compared using the Kruskall-Wallis analysis of variance, and the inter-group statistical comparisons were made using the Mann-Whitney $\mathrm{U}$ test.

RESULTS: The mean aqueductal flow rates were $46.56 \pm 25.06 \mathrm{ml} / \mathrm{min}$ for the INPH group, $9.28 \pm 4.68 \mathrm{ml} / \mathrm{min}$ for the AD group, and $8.68 \pm$ $3.40 \mathrm{ml} / \mathrm{min}$ for the control group. The mean flow rate of the INPH group was significantly higher than those of the control and ADH groups $(\mathrm{p}<0.001)$.
\end{abstract}

CONCLUSION: The mean CSF flow rate may be useful in the diagnosis and differential diagnosis, and the prediction of the potential benefits of surgical intervention for patients considered to have INPH.

KEYWORDS: Phase-contrast magnetic resonance imaging, Normal pressure hydrocephalus, Cerebrospinal fluid

ÖZ

AMAÇ: Faz kontrast manyetik rezonans görüntüleme kullanarak, idiyopatik normal basınçlı hidrosefali (iNBH) li hastalar ile atrofik dilatasyonu (AD) bulunan hastalarda akuaduktustaki ortalama beyin omurilik sıvısı (BOS) volümünü karşılaştırmak ve bu tekniğin cerrahi yararı öngörmedeki etkinliğini araştırmaktır.

YÖNTEM ve GEREÇLER: iNBH olarak değerlendirilen 30 hasta, serebral sulkuslar ile orantısız AD bulunan 20 hasta, hidrosefali kliniği bulunmayan kontrol grubu 30 olgu olmak üzere toplam 80 olgunun MR görüntüleri retrospektif olarak incelendi. Üç grup arasında akuaduktustaki dakikalık ortalama BOS debileri Kruskall-Wallis varyans analizi ile, gruplar birbirleri ile Mann-Whitney U testi ile istatistiksel olarak karşılaştırıldı.

BULGULAR: Akuaduktus düzeyinden elde edilen ortalama debi değerleri; iNBH grubunda 46,56 $\pm 25,06 \mathrm{ml} / \mathrm{dk}, \mathrm{AD}$ grubunda 9,28 $\pm 4,68 \mathrm{ml} /$ $\mathrm{dk}$, kontrol grubunda $8,68 \pm 3,40 \mathrm{ml} / \mathrm{dk}$ idi. iNBH grubundaki ortalama debi, kontrol grubu ve AD grubu ile karşılaştııılığında istatistiksel olarak anlamlı fazla bulundu ( $\mathrm{p}<0,001)$.

SONUÇ: Ortalama BOS debi oranları, INBH düşünülen olgularda tanıda, ayırıcı tanıda ve cerrahi yararı öngörmede faydalı olabilir.

ANAHTAR SÖZCÜKLER: Faz kontrast manyetik rezonans görüntüleme, Normal basınçlı hidrosefali, Beyin omurilik sıvıSı

\section{INTRODUCTION}

Normal pressure hydrocephalus (NPH), or chronic hydrocephalus according to its newly accepted name $(5,7)$, is seen more commonly in people of advanced age although it is a complex pathology that can be encountered at any age, starting from childhood. Classically, the dilatation of ventricles is seen with ataxia, urinary incontinence, and different grades of cognitive dysfunction. NPH may be idiopathic (INPH) or may occur as a result of subarachnoid bleeding, as in the case of tuberculoma meningitis, cranial traumas, or intra-cranial surgery $(4,12,16,21)$. Many diagnostic imaging techniques used in the diagnosis of NPH, such as radionuclide cisternogra- 
phy $(\mathrm{RC})$, computerized tomography (CT), CT cisternography (CTC), and magnetic resonance imaging (MRI). Nevertheless, all diagnostic imaging techniques describe false-positive and false-negative results $(1,2,9,18)$. The differential diagnosis of $\mathrm{NPH}$ is important as clinical recovery from the symptoms of $\mathrm{NPH}$ is possible after cerebrospinal fluid (CSF) diversion. However, not all patients heal after the shunt operation $(1,9,18,19)$. There is still no test that can accurately diagnose NPH patients or predict the potential benefit of surgical treatment $(1,2,9,19)$. A definitive diagnosis of NPH is only made by showing a clinical improvement after a shunt operation (13).

Compared with CTC and RC, phase-contrast MRI (PC MRI) has more advantages, including the capacity for multi-planar imaging, the absence of radiation, high soft tissue resolution, and the fact this it is noninvasive (3). In this study, our aim was to measure the minute mean CSF volume values in the aqueductus with PC MRI in patients considered to have either INPH or ventricular dilatation, and the normal population. We compared these three groups, investigated the contribution of the values obtained in the differential diagnosis of hydrocephalus, and attempted to predict the potential benefit of surgical intervention.

\section{MATERIAL and METHODS}

The MR images and charts of a total of 80 patients, consisting of 30 patients considered to have INPH according to their clinical and radiological features, 20 patients with atrophic dilatation (AD) disproportionate to the cerebral sulci, and 30 cases without any clinical characteristics of hydrocephalus. All these patients had been admitted to our department between January 2010 and April 2011 with various complaints, and these were investigated retrospectively. The study was approved by the ethics committee of Ondokuz Mayis University (Decision No: 2010/75). Patients with INPH were aged $19-80$ (mean age, $48.23 \pm 4.37$ years; 12 males and 18 females), patients with AD were aged 44-87 (mean age $67.19 \pm 3.46$ years; 17 males and 3 females), and patients without any clinical characteristics of hydrocephalus were aged 22-60 (mean age $43.36 \pm 2.81$ years; 15 males and 15 females). In 15 of the 30 patients who were determined to have INPH, ventriculo-peritoneal shunts (VPS) were placed, and follow-ups were done during the post-operative period.

\section{MR Imaging}

MRI studies were done with a 1.5 Tesla MR device (Magnetom, Symphony, Siemens Medical Systems, Erlangen, Germany) in the supine position and with the head in the neutral position using a standard head coil. The T2-weighted turbo spin echo images in the sagittal (TR/TE/NEX/FA: 6030/103ms $/ 1 / 150^{\circ}$ ) and axial (TR/TE/NEX/FA: 4270/108 ms $/ 2 / 150^{\circ}$ ) planes were obtained routinely while scanning the cranial region. The slice thickness was $5 \mathrm{~mm}$, the field of view (FOV) was $230 \mathrm{~mm}$, and the matrix was $256 \times 256$ in the sagittal images and $116 \times 256$ in the axial images.

Prospective cardiac triggering was applied to all subjects with electrodes compatible with MRI (Arbo, Kendall, Tyco
International Company, Germany). The plane of investigation in the T2-weighted midsagittal sections was perpendicular to the plane of midportion of the aqueductus $\left(90^{\circ}\right)$. The "localizer" line passed through the aqueductus in the axial plane.

The FLASH through-plane sequence was used in the semiaxial plane in PC MRI (TR/TE/NEX/FA: 33/7 ms /1/10 ${ }^{\circ}$ where the slice thickness was $3 \mathrm{~mm}$, the section width $1 \mathrm{~mm}$, the FOV $160 \mathrm{~mm}$, and the matrix $100 \times 256$. Velocity coding (Venc) was chosen as $20 \mathrm{~cm} / \mathrm{s}$ for all subjects. The FLASH inplane sequence was used in the sagittal plane (TR/TE/NEX/ FA: $43 / 12 \mathrm{~ms} / 2 / 10^{\circ}$ ) where the slice thickness was $4 \mathrm{~mm}$, the section width $1 \mathrm{~mm}$, the FOV $240 \mathrm{~mm}$, and the matrix $75 \times$ 256. Venc was chosen as $6 \mathrm{~cm} / \mathrm{s}$ for all subjects.

\section{Imaging Analysis}

All image clusters were transferred to a work station (Leonardo, software version 2.0, Siemens), and then the phase, rephrase, and magnitude images obtained by the FLASH through- plane and in-plane sequences in the semi-axial and sagittal planes were transferred to Argus image analysis software, which was used in the calculation of the flow and velocity parameters of the aqueductus. The results were obtained as graphics and tables. All MR images and calculated values were evaluated by two radiologists ( 7 and 16 years experience in radiology). The observers were fully blinded. The CSF flow was initially visually assessed in all subjects. The flow inside the aqueductus was seen with high-signal intensity in all sections in the phase and magnitude images, the flow in the cranial direction was seen at high-signal intensity, and the flow in the caudal direction was seen at low-signal intensity.

The regions of interest (ROIs) as a circle were placed on every slice, without passing outside the aqueductus borders in the phase and magnitude images. Data tables and graphic displays containing information on velocity $(\mathrm{cm} / \mathrm{s})$, current $(\mathrm{ml} / \mathrm{s})$ values, and the velocity time slope in one cardiac cycle were obtained in this way. A mean CSF flow rate of $1 \mathrm{~min}$ was calculated from the table. A mean CSF flow rate of $>18 \mathrm{ml} /$ $\mathrm{min}$ at the level of the aqueductus was considered to be a hyperdynamic CSF flow pattern.

\section{Statistical Analysis}

All statistical analyses were done with SPSS software (Statistical Package for Social Sciences, 15.0). The mean minute aqueductus CSF flow rates of the three groups were compared using the Kruskall-Wallis test. The inter-group statistical comparisons were made using the Mann-Whitney $U$ test. $P$ values of $<0.05$ were considered statistically significant.

\section{RESULTS}

One or more complaints, such as headache, imbalance, dementia, urinary incontinence, dizziness, and disturbance of walking, were present in the cases considered INPH ( $\mathrm{n}=$ 30). Four of these patients had the clinical triad of $\mathrm{NPH}$, i.e., dementia, urinary incontinence, and ataxia. VPS operations were performed on 15 of the 30 patients with INPH (8 males, 
7 females), and in all these patients an improvement in symptoms was observed in the postoperative period. In the other 15 patients, surgical interventions were not done during the course of this study, and postoperative data could not be obtained (Table I). The mean output value in the INPH group was $46.56 \pm 25.06 \mathrm{ml} / \mathrm{min}$ ( $\mathrm{min} .20 .25 \mathrm{ml} / \mathrm{min}$, max. $96.92 \mathrm{ml}$ / min) (Figure 1A-F).

One or more complaints, such as headache, imbalance, dementia, urinary incontinence, dizziness, and disturbance of walking, were present in the cases considered AD $(n=20)$. The mean output value in the $A D$ group was $9.28 \pm 4.68 \mathrm{ml} / \mathrm{min}$ (min. $1.24 \mathrm{ml} / \mathrm{min}$, max. $15.87 \mathrm{ml} / \mathrm{min}$ ) (Figure $2 \mathrm{~A}-\mathrm{H}$ ).

Cranial MRI studies were performed in 30 cases without the clinical picture of hydrocephalus, which constituted the control group. The mean flow rate in the control group was $8.68 \pm 3.40 \mathrm{ml} / \mathrm{min}$ ( $\mathrm{min} .3 .32 \mathrm{ml} / \mathrm{min}, \max .14 .67 \mathrm{ml} / \mathrm{min}$ ) (Figure $3 \mathrm{~A}-\mathrm{F}$ ). The mean and median flow rate parameters of the INPH, AD, and control groups are shown in Table II.

The Bonferroni correction was used to determine the origin of the mean flow rate difference between the groups, and it was found to originate from the INPH group. The mean and median flow rates of the INPH group were statistically significantly increased in comparison with the control and AD groups ( $p<0.001$ ). Although the mean and median flow rates of the $A D$ group was higher than the controls, there was no significant difference $(p>0.05)$ (Table II).

\section{DISCUSSION}

INPH is a CSF shunt-responsive syndrome relating abnormal gait, dementia and urinary incontinence without previous disorders, in the elderly (11). Two major alterations have been observed in CSF physiology during aging, namely, a decrease in CSF production and an increase in resistance against CSF flow $(12,13,15)$. Silverberg et al. (17) have suggested that Alzheimer's disease may develop when a decrease in CSF production predominates, but INPH may develop when resistance against CSF flow predominates. However, one of these disease processes increases the risk of the development of the other disease. On the other hand, among older volunteers, no significant difference has been shown between other cognitive disorders and CSF flow rate, and thus

Table I: Clinical Findings Observed in Patients Considered as INPH in Whom VPS Therapy was Applied

\begin{tabular}{|c|c|c|c|c|c|}
\hline $\begin{array}{l}\text { Patient } \\
\text { Number }\end{array}$ & Age & $\operatorname{Sex}$ & Clinical Findings & VPS & $\begin{array}{l}\text { Symptoms Decreased in } \\
\text { Postoperative Period }\end{array}$ \\
\hline 1 & 41 & $\mathrm{~F}$ & Imbalance, dementia, urinary incontinence & + & + \\
\hline 2 & 22 & M & Headache & + & + \\
\hline 3 & 35 & M & Imbalance & + & + \\
\hline 4 & 44 & $\mathrm{~F}$ & Headache, dizziness & + & + \\
\hline 5 & 73 & $\mathrm{~F}$ & Dementia, urinary incontinence, disturbance of walking & + & + \\
\hline 6 & 63 & M & Imbalance, urinary incontinence & + & + \\
\hline 7 & 46 & M & Headache, dizziness & + & + \\
\hline 8 & 54 & $\mathrm{~F}$ & Headache, dizziness & + & + \\
\hline 9 & 71 & $\mathrm{~F}$ & Dementia, urinary incontinence, disturbance of walking & + & + \\
\hline 10 & 70 & M & Dementia, urinary incontinence, disturbance of walking & + & + \\
\hline 11 & 22 & $\mathrm{~F}$ & Headache, imbalance & + & + \\
\hline 12 & 19 & $\mathrm{~F}$ & Headache, imbalance & + & + \\
\hline 13 & 43 & M & Headache, imbalance & + & + \\
\hline 14 & 38 & M & Headache, imbalance & + & + \\
\hline 15 & 28 & M & Headache & + & + \\
\hline
\end{tabular}

VPS: ventriculoperitoneal shunt.

Table II: Comparison of CSF flow Rates in Study Groups

\begin{tabular}{|c|c|c|}
\hline Group & Mean Flow $(\mathrm{ml} / \mathrm{min}) \pm$ SD & Median (min;max) \\
\hline Control & $8.68 \pm 3.40$ & $8.17(3.32-14.67)$ \\
\hline INPH & $46.56 \pm 25.06^{\beta, a}$ & $45.88(20.25-96.92)$ \\
AD & $9.28 \pm 4.68^{\&}$ & $9.02(1.24-15.87)$ \\
\hline
\end{tabular}

INPH: idiopathic normal pressure hydrocephalus, $\boldsymbol{A D}$ : atrophic dilatation, $\mathbf{S D}=$ Standard Deviation, ${ }^{\beta} p<0.0001$ compared to Control group, ${ }^{a} p<0.0001$ compared to $A D$ group, \& $p>0.05$ compared to Control group. 

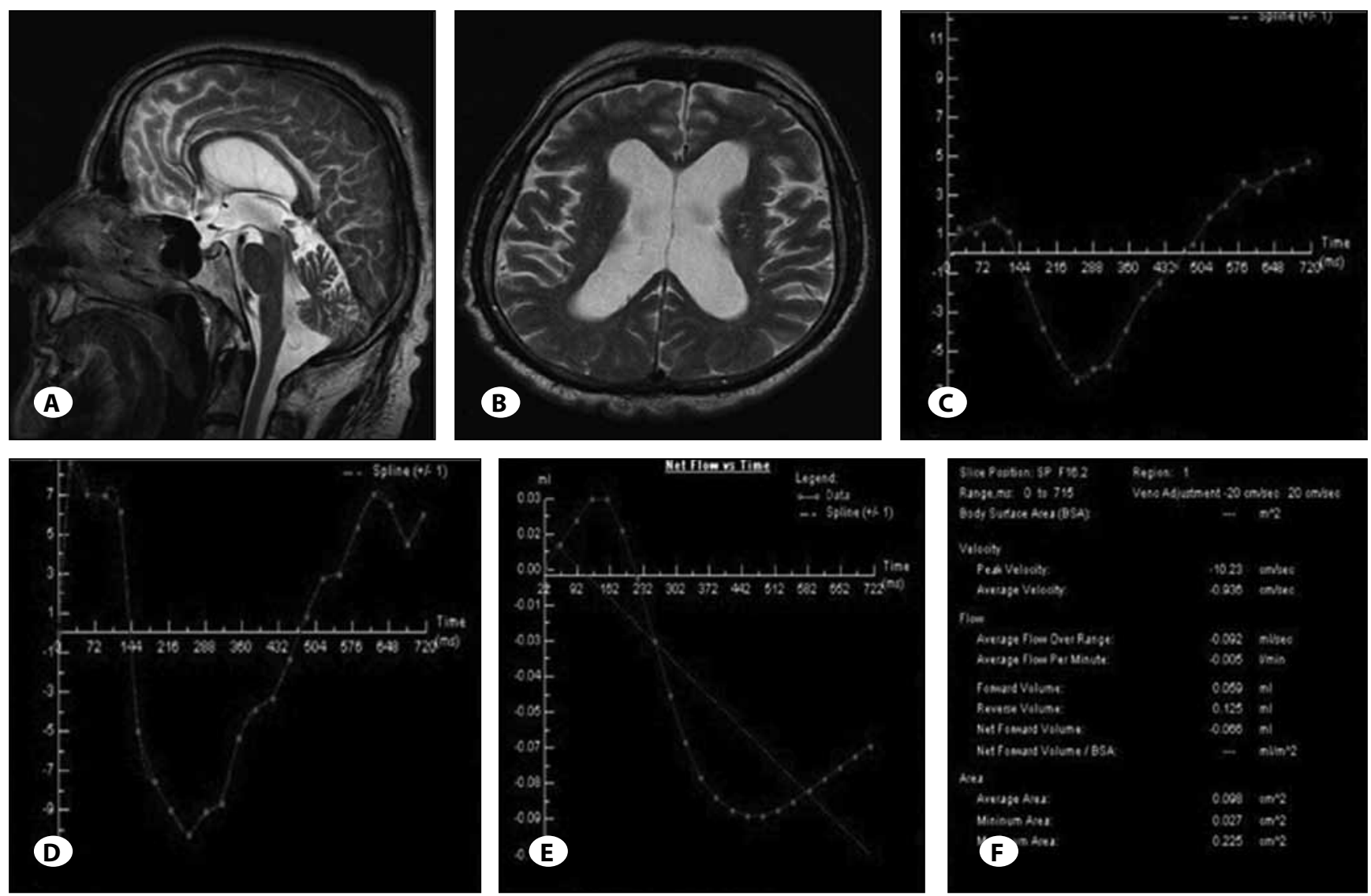

Figure 1: 66-year-old male patient complaining of imbalance and urinary incontinence. A) Sagittal and B) axial T2-weighted images reveal dilatation in the lateral and third ventricles, thinning in the corpus callosum, and the brain parenchyma tended towards convexity. C) The velocity time, D) peak velocity time, E) net flow time and F) data table of the aqueductal CSF flow study were obtained in the semi-axial plane. An increase in mean flow rate $(40.14 \mathrm{ml} / \mathrm{min})$ was observed.

investigators have concluded that flow-related parameters are independent of cerebral atrophy (17). In our study, the mean and median flow rates of the AD group were higher than the control group, but the difference wasn't statistically significant $(p=0.552)$.

In recent studies performed using phase-sensitive techniques, it has been pointed out that, in communicant hydrocephalus patients, aqueductal CSF flow is increased despite normal cerebral blood flow $(2,8,11,12,20)$. According to these studies, patients with symptomatic communicant hydrocephalus and marked signal loss in the aqueductus show better responses to VPS. In our study, VPS therapy was applied to 15 of the 30 patients, and post-operative symptoms were diminished in these patients.

Since the improvements in the PC-MRI examination, quantitative CSF flow studies aiming to determine CSF flow dynamics by examining the normal aqueductal CSF flow dynamics in NPH patients have increased. Various parameters, i.e., time, velocity, and flow, have been used to examine CSF flow dynamics $(8,14,10,20)$. There are differing opinions as to whether measuring aqueductal CSF flow velocity and flow rate contributes to a differential diagnosis of $\mathrm{NPH}$ or the prediction of the potential benefit from surgery. Some consider flow velocity and rate measurements adequate for a differential diagnosis and the prediction of the benefit from surgery, but others think the opposite $(4,11,14,17)$.

Mouton Paradot et al. (14) showed of the 14 hydrocephalus patients, 12 had a good response to the shunt. Of these, 10 presented an increased ventricular CSF flow. They reported PC-MRI can help improve guidelines for surgical management of NPH, and the shunt responders appear to be the patients with hyperdynamic ventricular CSF flow. Ginera et al. (10) emphasized PC-MRI is a useful tool for the early diagnosis of patients with $\mathrm{NPH}$. We regarded $18 \mathrm{ml} / \mathrm{min}$ as the threshold mean flow rate value in our study, and the patients with values above this were considered to have hyperdynamic CSF flow patterns and may therefore benefit from VPS therapy. By using PC-MRI, Bradley et al. (5) preoperatively measured the aqueductal CSF flow volume of 18 patients with a diagnosis of $\mathrm{NPH}$. The threshold value for increased flow volume was set at $42 \mu \mathrm{l}$. The flow volume was above $42 \mu \mathrm{l}$ in 12 of the 18 patients, and these patients benefited from surgery. In addition, three of the six patients with a flow volume below $42 \mu \mathrm{l}$ also benefited from surgery. Bradley et al. found $80 \%$ sensitiv- 

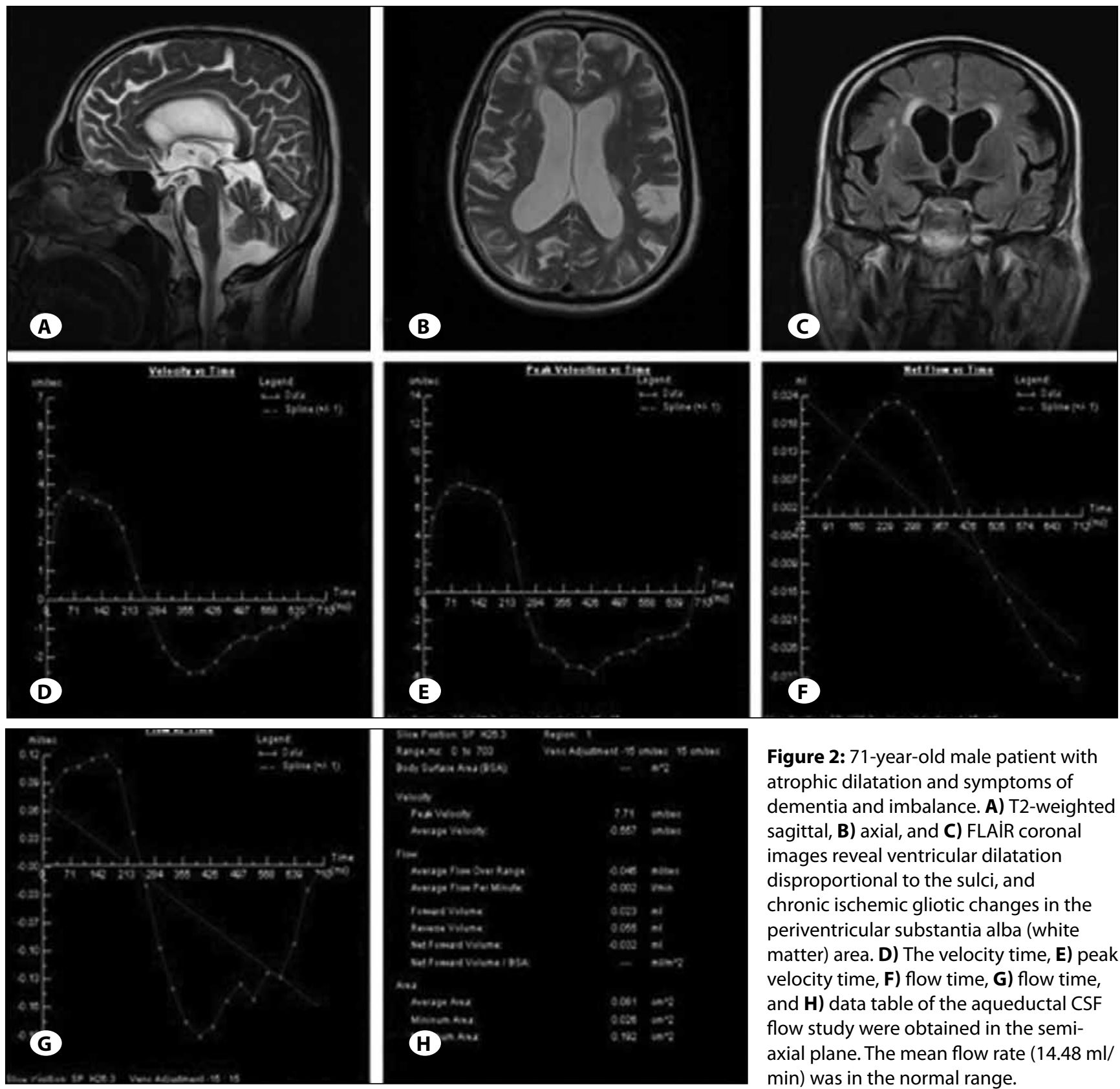

Figure 2: 71-year-old male patient with atrophic dilatation and symptoms of dementia and imbalance. A) T2-weighted sagittal, B) axial, and C) FLAiR coronal images reveal ventricular dilatation disproportional to the sulci, and chronic ischemic gliotic changes in the periventricular substantia alba (white matter) area. D) The velocity time, E) peak velocity time, F) flow time, G) flow time, and $\mathbf{H})$ data table of the aqueductal CSF flow study were obtained in the semiaxial plane. The mean flow rate $(14.48 \mathrm{ml} /$ $\mathrm{min}$ ) was in the normal range.

ity, $100 \%$ specificity, a $100 \%$ positive predictive value, and a $50 \%$ negative predictive value using this method. The study concluded that the aqueductal hyperdynamic CSF flow pattern may predict the benefit from surgery, and low aqueductal flow indicates atrophy. Our study is retrospective and we believe that a prospective study including postoperative and preoperative phase contrast MR findings will be more useful for objective prediction the benefits of surgical intervention in INPH patients.

In some studies, as an opinion stemming from the observation that some patients with normal aqueductal flow have responded to shunt therapy, it has been suggested not to regard normal aqueductal CSF flow measurements as a criteri- on in the decision-making regarding shunt therapy (6). Dixon et al. (6) concluded that there is no indication for a CSF flow examination before shunt therapy in patients with a clinical diagnosis of NPH whereas it may be a valuable tool in patients with a pre-diagnosis of NPH with inadequate clinical findings. In the latter case, an enhanced flow rate may imply that the patient will benefit from a shunt operation. In our study, VPS was performed in 12 of the 15 patients with a pre-diagnosis of INPH but an absence of both clinical findings and the INPH triad. A CSF diversion procedure was done for these patients with improved clinical findings. We observed that the algorithm of Dixon et al. (6) also revealed similar results in our study. 

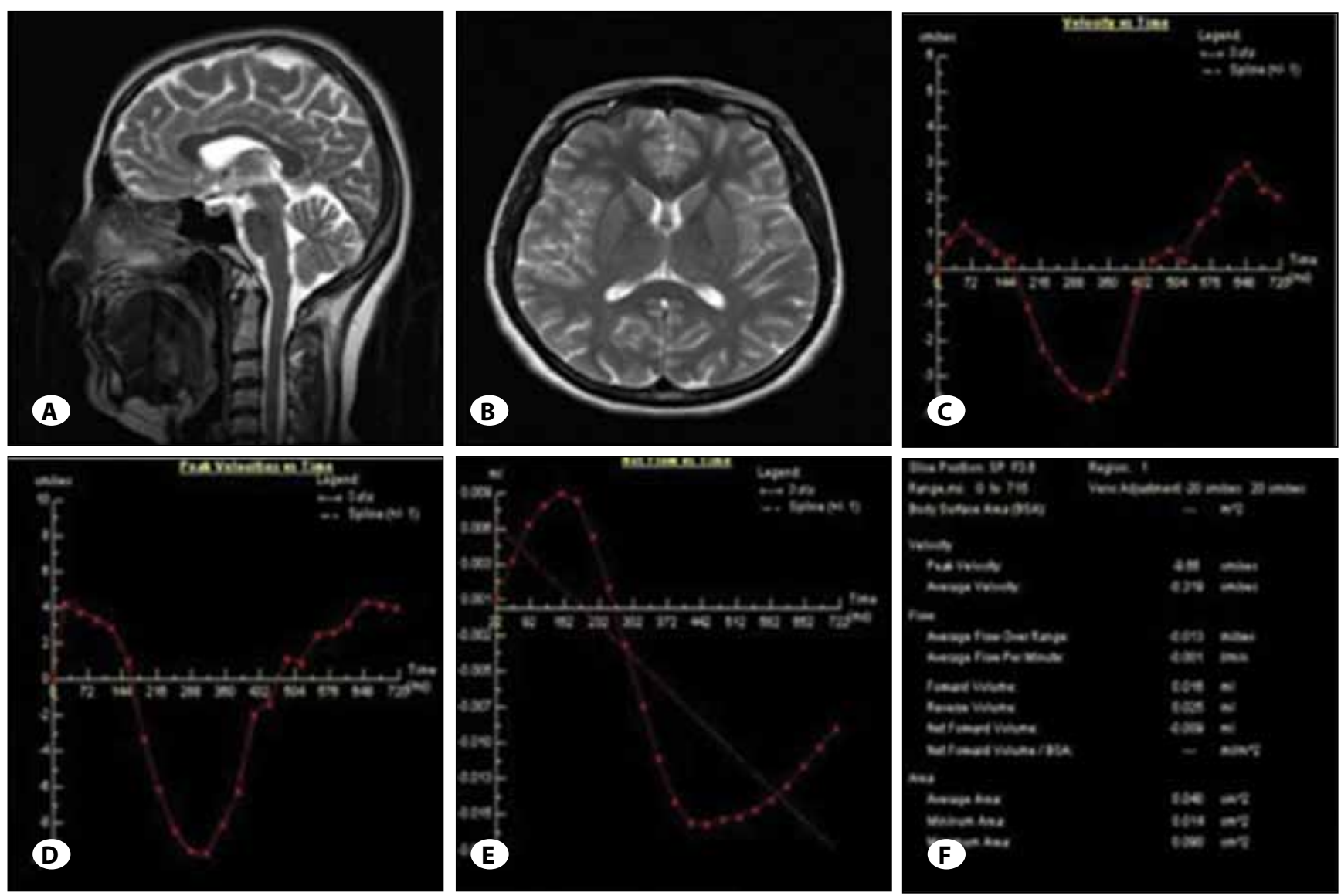

Figure 3: 46-year-old female from the control group. A) The T2-weighted sagittal and B) axial images reveal a normal ventricular system and sulci. C) The velocity time, D) peak velocity time, E) flow time, and F) data table of the aqueductal CSF flow study was obtained in the semi-axial plane. A velocity below 0 indicates flow in the caudal direction, namely CSF systole, and velocity above 0 indicates flow in the cranial direction, namely CSF diastole. The mean flow rate was $8.83 \mathrm{ml} / \mathrm{min}$.

In our study, the mean aqueductal flow rate was $9.28 \pm 4.68$ $\mathrm{ml} / \mathrm{min}$ with a median of 9.02 (min. 1.24 - max. $15.87 \mathrm{ml}$ / $\mathrm{min}$ ) in the atrophic dilatation group; $46.56 \pm 25.06 \mathrm{ml} / \mathrm{min}$, median 45.88 ( $\min .20 .25$ - $\max .96 .92 \mathrm{ml} / \mathrm{min}$ ) in the group considered INPH; and $8.68 \pm 3.40 \mathrm{ml} / \mathrm{min}$, median 8.17 (min. 3.32 - $\max .14 .67 \mathrm{ml} / \mathrm{min}$ ) in the control group. The mean and median flow rates were significantly higher in the INPH group compared to the other groups ( $<<0.001)$. There was no significant difference between the control and AD groups $(p=0.552)$. The main limitation of this study was the inability to determine the false-positive and false-negative rates of the CSF flow study since there is no gold standard to clinically confirm the diagnosis of INPH. Other limiting factor was the lack of postoperative MRI findings correlated with the clinical improvement in these patients.

\section{CONCLUSIONS}

The mean aqueductal CSF flow rate obtained through the quantitative measurement of aqueductal CSF flow may be useful in the diagnosis, differential diagnosis, and prediction of the potential benefit from surgery in patients with a prediagnosis of INPH.

\section{REFERENCES}

1. Algin O, Hakyemez B, Ocakoğlu G, Parlak M: MR cisternography: Is it useful in the diagnosis of normal-pressure hydrocephalus and the selection of "good shunt responders"? Diagn Interv Radiol 17:105-111, 2011

2. Algin O: Role of aqueductal CSF stroke volume in idiopathic normal-pressure hydrocephalus. AJNR Am J Neuroradiol 31:26-27, 2010

3. Arbelaez A, Medina E, Rodríguez M, Londoño AC, Castillo M: Intrathecal administration of gadopentetatedime glumine for MR cisternography of nasoethmoidal CSF fistula. AJR Am J Roentgenol 188:560-564,2007

4. Bateman GA, Levi CR, Schofield P, Wang Y, Lovett EC: The pathophysiology of the aqueduct stroke volume in normal pressure hydrocephalus: Can co-morbidity with other forms of dementia be excluded? Neuroradiology 47:741-748, 2005

5. Bradley WG, Scalzo D, Queralt J, Nitz WN, Atkinson DJ, Wong P: Normal pressure hydrocephalus: Evaluation with cerebrospinal fluid flow measurements at MR imaging. Radiology 198:523-529, 1996 
6. Bret P, Guyotat J, Chazal J: Is normal pressure hydrocephalus a valid concept in 2002? A reappraisal in five questions and proposal for a new designation of the syndrome as "chronic hydrocephalus". J Neurol Neurosurg Psychiatry 73:9-12, 2002

7. Dixon GR, Friedman JA, Luetmer PH, Quast LM, McClelland $\mathrm{RL}$, Petersen RC, Maher CO, Ebersold MJ: Use of cerebrospinal fluid flow rates measured by phase-contrast MR to predict outcome of ventriculoperitoneal shunting for idiopathic normal-pressure hydrocephalus. Mayo Clin Proc 77:509-514, 2002

8. Edwards RJ, Dombrowski SM, Luciano MG, Pople IK: Chronic hydrocephalus in adults. Brain Pathol 14:325-336, 2004

9. El Sankari S, Fichten A, Gondry-Jouet C, Czonsnyka M, Legars D, Deramond H, Balédent O: Correlation between tap test and CSF aqueductal stroke volume in idiopathic normal pressure hydrocephalus. Acta Neurochir Suppl 113:43-46, 2012

10. Graff-Radford NR: Normal pressure hydrocephalus. Neurol Clin 25: 809-832, 2007

11. Ginera JF, Sanz-Requena R, Flórez N, Alberich-Bayarri A, García-Martía G, Ponz A, Martí-Bonmatí L: Quantitative phasecontrast MRI study of cerebrospinal fluid flow: A method for identifying patients with normal-pressure hydrocephalus. Neurología (Epub ahead of print), 2013

12. Ishikawa M, Hashimoto M, Mori E, Kuwana N, Kazui H: The value of the cerebrospinal fluid tap test for predicting shunt effectiveness in idiopathic normal pressure hydrocephalus. Fluids Barriers CNS 9(1):1,2012

13. Luetmer PH, Huston J, Friedman JA, Dixon GR, Petersen RC, Jack CR, McClelland RL, Ebersold MJ: Measurement of cerebrospinal fluid flow at the cerebral aqueduct by use of phase-contrast magnetic resonance imaging: Technique validation and utility in diagnosing idiopathic normal pressure hydrocephalus. Neurosurgery 50:534-542, 2002
14. May C, Kaye JA, Atack JR, Schapiro MB, Friedland RP, Rapoport SI: Cerebrospinal fluid production is reduced in healthy aging. Neurology 40: 500-503, 1990

15. Mouton Paradot G, Baledent O, Sallioux G, Lehmann P, Gondry-Jouet C, Le Gars D: Contribution of phase-contrast MRI to the management of patients with normal pressure hydrocephalus: Can it predict response to shunting? Neurochirurgie 56:50-54, 2010

16. Parkkola RK, Komu ME: Cerebrospinal fluid flow in children with normal and dilated ventricles studied by MR imaging. Acta Radiol 42: 33-38, 2001

17. Sasaki M, Honda S, Yuasa T, Iwamura A, Shibata E, Ohba H: Narrow CSF space at high convexity and high midline areas in idiopathic normal pressure hydrocephalus detected by axial and coronal MRI. Neuroradiology 50:117-122, 2008

18. Silverberg GD, Mayo M, Saul T, Rubenstein E, McGuire D: Alzheimer's disease, normal-pressure hydrocephalus, and senescent changes in CSF circulatory physiology: A hypothesis. Lancet Neurol 2:506-511, 2003

19. Stein SC: Normal-pressure hydrocephalus: An update. Neurosurgery Quarterly 11:26-35, 2001

20. Vanneste JAL: Diagnosis and management of normal pressure hydrocephalus. J Neurol 247:5-14, 2000

21. Woodworth GF, McGirt MJ, Williams MA, Rigamonti D: Cerebrospinal fluid drainage and dynamics in the diagnosis of normal pressure hydrocephalus. Neurosurgery 64: 919-925,2009

22. Yasar K, Pehlivanoglu F, Sengoz A, Sengoz G: Evaluation of radiological findings in 160 adult patients with tuberculous meningitis. Turk J Med Sci 42:259-267, 2012 